\title{
Between Text and Performance: On the Productive Reception of H. C. Andersen's Fairy Tales by the Slovak Radio
}

\section{Intersemiotic Translation as a Form of Reception}

History of translation is closely connected with the process of its reception. Beside translated texts, reception also includes "accompanying texts, as well as interpretations, references and miscellaneous interrelations" (Vajdová 2009: 238). In fact, translation (like any text) only exists when it is read, interpreted, discussed, etc. Particular forms of reception were classified by the German scholar Hannelore Link who distinguished between passive, reproductive and productive reception (2009: 89-90). Her classification may be extended by the fourth category, i.e. translation, which the Slovak literary scholar and comparatist Dionýz Durišin considered to be a "specific form" of reception (1985: 128). These four forms of reception create a complex system. First, passive reception can be understood as an essential step a reader takes towards the work, but does not necessarily lead to any further scholarly or artistic creation. Second, reproductive reception refers to the process of reading which is followed by creating a new literary-critic or literary-historic text dealing with and directly referring to its primary source (a review, an afterword, a monograph, etc.). Third, translation is a result of reading a text with the aim of creating its variant in another language. And fourth, productive reception includes all texts which arise as results of creative transformation of the primary text and now represent an independent piece of art (parody, allusion, etc.). Apart from this, the process of creative transformation is not restricted to printed texts only but also includes adaptations for other media, such as radio, theatre or film. 
In his essay On Linguistic Aspects of Translation (1959), Roman Jakobson proposed three types of translating (i.e. interpreting) a verbal sign: intraligual translation (i.e. rewording), interlingual translation (i.e. translation proper) and intersemiotic translation. He defined intersemiotic translation, also referred to as transmutation or intersemiotic transposition, as an "interpretation of verbal signs by means of signs of nonverbal sign systems" (Jakobson 1959). By naming music, dance, cinema or painting as examples of transformation possibilities of verbal art, Jakobson opened the term of intersemiotic translation to arts employing both one and more than one creative techniques. This allows us to consider, for example, radio adaptations as intersemiotic translations, too - although the verbal part (characteristic for the field of written literature) still constitutes its basis and only is enriched by the acoustic dimension. In this way, it is the creative transformation of existing work accompanied by changing or adding a sign system, which can be seen as a criterion/definition of intersemiotic translation. The process can also be described as "aesthetic re-creation", as Haroldo de Campo has put it (qtd. in Pereira 2008: 106).

Jakobson's term of intersemiotic translation was accepted by the Slovak translation theoreticians and included into the classification of translation. In 1975, the crucial work of Slovak translation studies was published by Anton Popovič under the title Teória umeleckého prekladu [The Theory of Literary Translation]. Referring to the influence of linguistic semiology, he defined intersemiotic translation as "a sort of intersemantic transformation, e.g. from the language of literature into the language of film, from the language of fine arts into the language of music, etc." (Popovič 1975: 22). Later, the definition was also taken into the dictionary of interpretation terminology Originál/preklad [Original/Translation] from 1983. In spite of drawing inspiration from Jakobson, Popovič does not strictly operate with the term "sign system" but adds the term "language" into the discussion (the language of film, for instance, implicitly including the verbal, the visual and the acoustic). In this way, he shifts the perspective from the semantic point of view to the medial one, though without offering any further explanation.

Understanding intersemiotic translation as creative transformation based primarily on the usage of a different medium and not necessarily on a complete change of the sign system opens up a space for analysing various sorts of productive reception - be it in the field of literature, music, visual arts, theatre, radio, etc. In the process, the original piece of art is adapted for a new medium. As Gideon Toury says, this medium operates within the limits of its own repertoire of tools and models (qtd. in Weissbrod 2006: 44). Therefore, the level of dependence on the primary piece of art results not only from the 
authorial (i.e. creative) contribution of the adaptor and his aim of preserving/ deconstructing the original meaning but also from the creative possibilities given by the chosen medium (e.g. sound cannot be transferred to picture by employing the same tools as in composition, for instance). On one hand, the quality of intersemiotic translation as such does not allow all the features of the prototext (i.e. the original written literary text) to be transformed for the new media. On the other hand, new elements are added to the work, thus creating a new - and in many ways independent - piece of art. Nevertheless, if the intersemiotic transposition aims at meeting the criteria of translation, the set of meanings which are constant, constitutive and unchangeable need to be preserved in the new form, too. This set of meanings defines Popovič as the "invariant" (Popovič 1983: 174). In an adaptation (intralingual, interlingual, or intersemiotic), the invariant core is what has been left untouched by selection, substitution, or condensation (see Popovič 1983: 154).

\section{Slovak Reception of Hans Christian Andersen's Literary Work}

The Slovak reception of H. C. Andersen developed in a context of rising international recognition of an author, whose novel The Improvisatore brought him success in the German area in the 1830's and later also among the Russian, English and French critics and readers. In the 1840's, first translations started to appear also in Czech and Polish periodicals and in the next decade, they were followed by respective translations of Andersen's first novel. However, while the early translation reception of the author in these areas is connected to the novel genre, the first phases of Slovak reception process only are based on his tales.

The first Andersen's magazine translation into Slovak was recorded in 1867, when the Sokol magazine published his tale "Múdri ludia" (i.e. "Emperor's new Clothes") translated by Viliam Paulíny-Tóth. A new wave of interest arose in 1875, when the Orol magazine published six tales translated by Andrej Truchlý Sytniansky, the editorin-chief himself. The tales were presented as counterparts of domestic folk legends of the Slovak nation. A transition from magazine to book translation only occurred in 1888 when František Macvejda, a teacher, prepared a selection of twelve texts by Andersen. Next selection was prepared by another teacher, Cyrill Gallay, no sooner than in 1911. As it contributed to enlivening the literary production for children and youth of the time, the collection was highly appreciated by contemporary critics. 
The first half of the $20^{\text {th }}$ century brought several book selections, translated or edited by Michal Slávik (1922; 1925), Anton Macht (1930), Michal Kubiš (1935), Eva Orolimová (1945), Štefan Koperdan (1945), and Mária Rumplová (1947). However, analyses and evidence show, that all of them worked with a translation into a third language or with an already existing Slovak variant. The method of relay translation reflected itself in a number of negative shifts of meaning. First translations directly from Danish came to existence in the 1950's thanks to Jaroslav Kaňa who translated 108 tales published in a dozen of collections during his career - many of them in numerous reeditions. Kaňa proved himself as a skilful translator and despite several semantic shifts and language imperfections, his texts are smooth to read. It was mainly in the first phase of his active work that censorship (introduced in Czechoslovakia during the Communist period after 1948) influenced the target texts. The period also left its trace in the selection of tales and in eliminating or substituting religious motifs.

After the revolution in 1989, the translation reception of H. C. Andersen's work has been typical for two streams. There is a group of educated translators working directly with the Danish original (J. Kaňa, M. Richter, M. Žitný) and a group of creators who produce Slovak versions of adapted 298 variants in a third language. And it is the latter group that reflects the model of receiving Andersen as an exclusive children writer. This is to be seen mainly in eliminating unsuitable passages (violence, realities, and irony), dynamization of static elements, or interventions on the level of meaning with the aim to soften the text. By promoting definite number of tales, the adaptations also contribute to reducing Andersen's work to approximately ten texts, copying the situation in the world. The picture is only partly disturbed by extensive collections by Kaňa, Richter, and Žitný, which to a certain extent also reflects the discussion about the (non-)intentional character of the author's tales.

At the beginning, Slovak translations of Andersen substituted the deficient domestic non-didactic literature for children and later (in the 1920's and 1930's) functioned as its complements and stimuli. After the World War II, Kaňa's translations anchored the receiving of Andersen's work in the target culture and their function became more informative and representative. In spite of Andersen's tales and stories having become more of a tradition, their livingness is reflected in other fields of art. Radio and theatre have drawn inspiration from them since 1950 's and produced dramatizations as well as radio or theatre plays. Moreover, the field of productive reception also includes literary texts, fine arts (illustrations), music (operas as well as popular songs), etc. 


\section{Productive Reception by the Slovak Radio}

When looking for the first traces of Hans Christian Andersen in the Slovak Radio (established in 1926), one has to bear in mind that the archives only provide information from approximately 1950's. However, first Andersen's tale must have been broadcast even earlier, which is also proved by a book of radio tales from the 1930's that includes four of his texts (edited by Hana Gregorová). Nevertheless, the beginnings of Andersen's presence in the (Czecho)Slovak Radio are to be associated with the so-called monological readings, i.e. readings of already existing translations into Slovak. Only in 1953 plays were introduced to the programme. Their final shape was also a result of ideological intentions (see Lefevere 1992: 14): the programme was called "Sunday fairy-tale" and was meant to distract children from attending Sunday masses. Radio plays had to follow two main criteria at that time: length (app. 40 minutes) and ideology (no religious motifs, optimistic outcome).

Between 1954 and 2010, Andersen's tales were broadcast at least 240 times by the Slovak Radio, the number of them continuously rising:

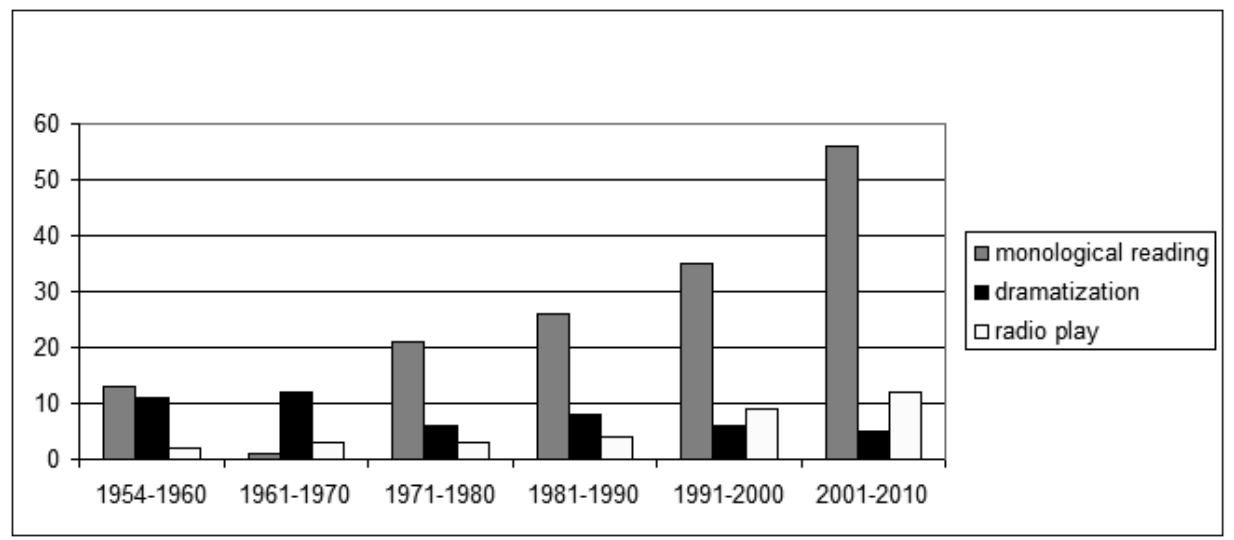

Figure 1. Broadcast tales according to genres

The numbers include both premieres and repeated broadcastings of the same recording, which partly opens the question, whether the reception of the Danish author was rather a matter of living interest or of mere tradition.

As for the genre classification, the list of broadcast tales consists of three types of radio form: 
1. Monological readings, i.e. readings of existing published translations with no or minimal intervention into the text of translation and length not exceeding 10 minutes;

2. Dramatizations, i.e. prose transformed into drama but making use of original the text (when possible);

3. Radio plays, i.e. plays written directly for the radio, which result from a strong creative input of the author, often introduced by words "on the motifs of $X Y^{\prime \prime}$ and lasting app. 45 minutes.

Monological readings are pure reproductions of literary texts by means of radio broadcasting. The only tools specific for the radio as a media that are allowed here are voice modulations. Though acoustic dimension being added, the original text is left without change and almost no creative transformation can be observed. From this perspective, monological readings can only be understood as minimalistic variants of transferring the "language of literature" into the "language of radio" and as they lack the creative aspect, we do not consider them to be intersemiotic translations proper.

Dramatizations already integrate the language of acoustic drama into the process and radio plays show even greater deviation from the original text. Therefore - by combining change of the media and creative transposition of the original piece of art - they stand closer to the field of productive reception and both can be treated as intersemiotic translations. As for their position towards original, the relationship is similar to the one between "faithful" and "free" translations and depends on the aims and intentions of the adaptor.

An overview of the most broadcast Andersen's fairy-tales copies the situation with the published literary translations. Genre classification not being taken into consideration, the tales "The Ugly Duckling", "The Snow Queen", "The Hardy Tin Soldier", "The Nightingale", "The DarningNeedle" as well as "The Little Sea Maid" belong to the most preferred. However, the stories "Wild Swans", "The Emperor's New Clothes" or "Thumbelina" have inspired a number of radio plays and dramatizations as well, especially in the period of 1990's.

\section{Case Study: H. C. Andersen's “Wild Swans" Adapted by Peter Gregor (1992)}

As defined by the Slovak scholar Pavol Palkovič, "dramatic works for radio are often described as one-dimensional theatre [...] because the piece of art can only be perceived by hearing" (1974:36). Due to the exclusivity of 
acoustic perception, radio plays and dramatizations should meet several criteria: (1) the plot should be simplified and condensed; (2) the number of figures reduced, and (3) the text easily perceptible (e.g. by means of the dialogues). Moreover, direct communication with the audience should be strengthened by employing sound effects and music, which create both the background of the story and its emotional load. Bearing this in mind, a look shall now be taken at the adaptation of H.C. Andersen's tale "Wild Swans", premiered by the Slovak Radio on May, $17^{\text {th }} 1992$ and adapted by Peter Gregor. The example passages are taken both from Andersen's translation into English from 2009 and from the original script to the radio drama adapted by Peter Gregor (the particular passages are translated by the author of this paper).

H. C. Andersen tells a story of eleven brothers and one sister, the twelve children of a king and his second wife, their step-mother (who is not very friendly with them, as it usually goes). As the queen can't stand the brothers, she casts a spell over them and turns them into swans. Their sister Eliza comes back from the country and finds out that her brothers are gone. Later, as a result of the queen's hostility, she leaves the palace, too. In the woods, Eliza meets an old woman who shows her eleven swans floating on the nearby lake and Eliza recognizes her brothers. Together they fly to a foreign country. In a dream, Eliza finds out how to break queen's spell and turn her brothers into young men again: she needs to collect nettles and sew eleven shirts, but must not say a word during her work. In the meantime, a young prince falls in love with her. His archbishop, however, doesn't like Eliza. He spies on her and watches her visiting the cemetery at midnight, picking nettles. He labels her as a witch and requests her to be burnt to death. However, in the last moment the swans come flying, Eliza throws the nettle-shirts on them and they become princes again.

Andersen's text is more lyrical-epical than dramatic and is characteristic for its long descriptive passages and monologues. It abounds in depicting nature and reflecting frames of mind and does not avoid religious and folk references. On the other hand, the dramatic potential can be suspected in dialogues (not seldom marked by irony and humour), repetitive motifs, or folk-tale elements. How has Peter Gregor treated the material at his disposal when taking into consideration the criteria set upon radio drama? Which tools of the radio language did he use? 


\section{A. Condensing the story and developing action-loaded passages}

Peter Gregor is a skilful writer who adapts the original Andersen's text according to presumed expectations of the audience. He makes use of naturalization strategies and changes the protagonist's name from the Danish Eliza into Slovak Elenka. He also directly connects Andersen's story with the domestic folk tradition and instead of swans, there are crows featuring in his play. Nevertheless, the script of his radio drama is indisputably based on the story by $\mathrm{H}$. C. Andersen, as whole sentences and structures can be identified as taken over word by word from the Slovak translation of the Danish author. Although these strategies only help the listeners to create a frame of the story more easily, several further changes are necessary to be incorporated on the structural level in order to make prose into drama. One of them is developing the dramatic potential of the text.

As stated before, descriptions and monological passages make up the repertoire of literature but do not effectively function with acoustic forms - mainly due to increased demand of attention required from the listeners. They do not push the story forward and that is the reason why 302 Peter Gregor simplifies the fable and eliminates chosen parts. For instance, he completely omits the passage describing the twelve siblings flying to another country, which in book form makes up two pages. The same is true for the story line taking place at the forest: there is no old woman in Gregor's version, no meeting with the brothers at the lake, no longwinded retelling of Eliza's dream. Instead, the radio play introduces new figures on the scene - the River and the Willow Tree - they tell Eliza about her brothers' fate as well as about the possibility to rescue them. At the same time, the passage is retold in the language of radio. Although it preserves the lyrical dreamy mood, the story is given by means of dialogues, not by monological narration.

Hans Christian Andersen (2009: 152)

(Eliza having a dreamy vision of an old woman)

Your brothers can be released, said she. But have you courage and perseverance? Certainly, water is softer than your delicate hands, and yet it changes the shape of stones; but it feels not the pain that your fingers will feel; it has no heart, and does not suffer the agony and torment you will have to endure. Do you see the stinging-nettle which I hold in my hand? Many of the same kind grow around the cave in which you sleep [...]. 
Between Text and Performance: On the Productive Reception...

Peter Gregor (1995: 8)

Elenka: $\quad$ I have seen them in the garden [...] And the River told me about them, too [...]. Is it them? My brothers?

Willow Tree: Yes, it is them. They were enchanted.

Elenka: Where are they? Where have they flown to?

Willow Tree: There [...] to the country on the other side of the river.

Elenka: I will go there and save them. But [...] how can I break the horrible spell?

Willow Tree: Can you see the nettle growing on the banks?

Elenka: Yes, I can! How high and dense it grows!

Willow Tree: And can you see the flax?

Elenka: Yes, I can! The fields are full of it [...].

Willow Tree: Although the water is softer than your hand, it can turn stone into sand. But the water does not feel the pain your hands will feel, when collecting nettle and flax in order to turn them into thread.

The invariant information is preserved in both the original and its adaptation: Elizabeth gets to know how to release her brothers. The difference lies in the tools being used as well as in the emphasis put by Peter Gregor on the interactive aspect of the dialogical form.

\section{B. Making the text more easily perceptible by introducing colloquial speech}

Peter Gregor attempts at making the lyrical parts more dynamic not only by transferring them from the narrator's speech into the speech of figures (as shown above) but also by making them more attractive on the level of language. By using the rhythm of colloquial speech, he enters the field of expressiveness and adds emotional dimension to the original text. To be able to develop his strategy, he focuses on conflict-bearing figures, such as the queen, and creates new situations in which their temperament might be verbalized. Doing so, he moves away from the original and creatively transforms the prototext by means of the radio language.

Hans Christian Andersen (2009: 143)

The next week the Queen took the little sister Eliza into the country, to a peasant and his wife; and but a short time had elapsed before she told the King so many falsehoods about the poor princes that he did not trouble himself any more about them.

"Fly out into the world and get your own living", said the wicked Queen. "Fly like great birds without a voice".

But she could not make it so bad for them as she would have liked, for they became eleven magnificent wild swans. 
Peter Gregor (1995: 3-4)

(The queen asks her husband to get rid of the princes as she cannot stand them anymore. He promises to conquer twelve kingdoms for them)

Queen: /laughing/ Have you already forgotten, that your old famous armour does not fit you anymore? And even if it did, that you are not able to mount your horse? And even if you would, that the horse breaks in two under the pounds of yours? And even if it didn't, that it would last tooooo long for you to conquer the twelve richest countries of the world, because you are old and fat. And I will not wait that long! I won't, I won't! I will take care of everything by myself.

Sound: $\quad$ music motif

Queen: $\quad$ lechoed/ All of you, turn into black birds! All of you, turn into crows and fly! Fly into the world, I don't want to see you anymore! Fly! Fly!

Sound: the motif of transformation, craws, music

In Andersen's original, the queen prepares the act of casting a spell over the princes by intrigues and badmouthing. In Gregor's variant, she prefers an open argument with the king - a solution which is more expressive on the level of language, more dynamic and at the same time more applying to the audience.

\section{Reducing the number of figures}

The tale "Wild Swans" does not belong to stories with a very high number of characters, therefore no considerable reduction of their amount has been observed in this particular case. On the contrary, Gregor adds new figures but not to make the plot more complicated. Rather to emphasize the emotional load of it - for instance, in the final scene when Eliza is standing on the stake and waiting for her death. Gregor makes Andersen's single man's cry to a cry of a mass, which adds dynamics and emotion to the story.

Hans Christian Andersen (2009: 158)

Look at the witch, how she mutters! She has no hymn-book in her hand; no, there she sits with her ugly sorcery - tear it in a thousand pieces!

Peter Gregor (1995: 17)

Voice 5: What does she have in her hands?

Voice 1: Look, people! It is shirts!

Voice 3: $\quad$ From nettle and flax! From nettle and flax has she sewed them, the witch!

Voice 1: Put her into flames!

Voice 2: Burn her to death! 
Although the number of characters actually is enlarged, we may consider the crowd as one collective character, which also underlines the hysteria provoked by the archbishop. Moreover, by dividing the monologue of the original into cries of more people, the acoustic perception of the situation is prolonged and the suspense intensified.

\section{Using music as (emotional) background}

As already said, sound effects multiply the emotional load of spoken words. Whereas emotions and psychological state of mind usually are described by long passages in literary texts, radio drama often uses the tool of music. In the case of Gregor's adaptation of "Wild Swans", sound effects help to evoke both negative (fear, danger, evil) as well as neutral or positive emotions (joy, security, peace). Acoustic transformation makes the experience of listening to the story stronger and increases the listener's ability to internalize protagonists' feelings.

Hans Christian Andersen (2009: 155-156)

There, on one of the broadest tombstones, she saw sitting a circle of lamias [...] Eliza was obliged to pass close by them, and they fastened their evil glances upon her; but she prayed silently, and collected the burning nettles, and carried them into the castle.

Peter Gregor (1995: 12)

Sound: an owl howling a choir of screeching and dull voices being heard Who is it creeping there at midnight?

Who is it searching there for something?

You don't know? It is Elenka from the king's palace [...]

/voices repeating/

$$
\begin{aligned}
& \text { Elenka? } \\
& \text { Elenka? } \\
& \text { Elenka [...] }
\end{aligned}
$$

Adding music and sound effects to the text represents one of the major advantages of the radio language when compared to the language of literature. In the passage above, sound effects are used to evoke fear on the side of both Elenka and the (child) listener. To achieve this goal, they effectively employ stereotypes in the process (e.g. a howling owl as a symbol of a dark forest). 


\section{Conclusion}

Transforming literary texts into other types of arts and media is a widely-used practice. This sort of creative transformation includes not only a change in the way of mediating the message carried by the work itself, but also a change in the tools used during the process. However, as intersemiotic translation is defined as a transfer from one sign system into another (R. Jakobson) or as a transfer from one "language" into another (A. Popovič), it allows us to analyse the adaptations of literary works in the light of possibilities offered by the medium chosen. The paper outlined some features of radio adaptations and of the process of transferring written word to a word "performed" - even if only acoustically.

Radio adaptations - understood as intersemiotic translations - occupy the position between reproductive and productive reception of a literary work and according to the extent of their faithfulness to the original/ pretext, they can be described as "faithful" or "free" - as any other sort of translation. Nevertheless, creative transformation accompanied by the change of the medium also causes negative shifts with regard to the message transferred. As two different media (in our case literature and radio) do not have the same repertoire of tools at their disposal, it is not possible for the entire set of meanings to be preserved in the new form. Nevertheless, the invariant set of meanings of the original piece of art is preserved in the process of intersemiotic translation. It is the outer form and the way of displaying the invariant, which undergoes changes. The language of radio is typical for its dynamics, expressiveness and emotionality (often underlined by music or sound effects) and it is these three qualities that form pillars of radio drama production. This was also proven by an analysis of intersemiotic translation of H. C. Andersen's "Wild Swans" by Peter Gregor.

\section{References}

Andersen, Hans Christian (2009). The Complete Fairy Tales. London: Wordsworth. Ďurišin, Dionýz (1985). Teória literárnej komparatistiky. Bratislava: Slovenský spisovatel'.

Gregor, Peter (1995). Elenka a kŕdel havranov. Bratislava: Archív slovenského rozhlasu. Script and recording Nr. SCD-000201.

Jakobson, Roman (1959). On Linguistic Aspects of Translation. Culturalstudiesnow. blogspot.sk. [accessed Feb. 10, 2014]. 
Lefevere, André (ed.) (1992). Translation/History/Culture. A Sourcebook. London: Routledge.

Link, Hannelore (1980). Rezeptionsforschung. Eine Einführung in Methoden und Probleme. Stuttgart: Kohlhammer.

Palkovič, Pavol (1974). Epika a dráma. Javisková dráma a rozhlasová hra. Bratislava: Československý rozhlas.

Pereira, Nilce M. (2008). “Book Illustration as (Intersemiotic) Translation: Pictures Translating Words". Meta: Journal des Traducteurs / Meta: Translator's Journal 53 (1): 104-119. Erudit.org. [accessed Feb. 10, 2014].

Popovič, Anton (1975). Teória umeleckého prekladu. Bratislava: Tatran.

Popovič, Anton (1983). Originál - preklad. Interpretačná terminológia. Bratislava: Tatran.

Vajdová, Libuša (2009). Sedem životov prekladu. Bratislava: VEDA.

Weissbrod, Rachel (2006). "Inter-semiotic Translation: Shakespeare on Screen". Journal of Specialized Translation 5: 42-56. Jostrans.org. [accessed Feb. 10, 2014]. 